\title{
CARACTERÍSTICAS DA VARIABILIDADE E DO CLIMA URBANO EM MARINGÁ- PR
}

Resumo: Buscou-se caracterizar a variabilidade climática de Maringá-PR e avaliar as características termodinâmicas de uma área amostral. Para isso utilizou-se uma série histórica de dados de 1980 a 2019 e 42 transectos móveis noturnos de temperatura e de umidade relativa do ar. Utilizou-se o método de regressão polinomial para a interpolação dessas variáveis. Os resultados da análise da variabilidade climática foram: quantidade equiparada de anomalias positivas e negativas de chuva na série histórica, mas de 2013 a 2018 houve uma sequência dessas anomalias positivas; anomalias negativas de temperatura média do ar, principalmente na década de 1980; e redução dos valores anuais médios de umidade relativa do ar de 2000 a 2019. Quanto à análise dos transectos móveis, observou-se uma célula de aquecimento com diferenças de $6,5^{\circ} \mathrm{C}$ de temperatura e $36 \%$ de umidade em relação ao seu entorno.

Palavras-chave: Variabilidade Climática. Transecto Móvel. Medições Termohigrométricas. Características Termodinâmicas.

\section{CHARACTERISTICS OF NOCTURNAL MOBILE TRANSECTS OF TEMPERATURE AND RELATIVE AIR HUMIDITY IN A SAMPLE AREA OF MARINGÁ-PR}

Abstract: The aim of this paper was to characterize the climatic variability of Maringá-PR and to evaluate the thermodynamic characteristics of a sample area. The dataset is composed of a historical series (1980-2019) and 42 nocturnal mobile transects of temperature and air relative humidity. The polynomial regression method was used to interpolate these variables. The results from climatic variability analysis were: there is a similar number of positives and negatives rain anomalies in the timeseries, however, between the years 2013 to 2018 there was a sequence of positive anomalies; negative anomalies of average air temperature, mainly in the 1980's; and reduction of average annual air relative humidity from 2000 to 2019 . In relation to mobile transects analysis, it was observed a heating cell with maximum values of difference of $6,5^{\circ} \mathrm{C}$ of temperature and $36 \%$ of air relative humidity compared to its surroundings.

Keywords: Climate Variability. Transect Mobile. Thermohygrometric Measurements. Thermodynamic Characteristics.

\section{CARACTERÍSTICAS DE TRANSECTOS MÓVILES NOCTURNOS DE TEMPERATURA Y HUMEDAD RELATIVA DEL AIRE EN UNA ZONA DE MUESTRA DE MARINGÁ-PR}

Resumen: Se buscó caracterizar la variabilidad climática de Maringá-PR y evaluar las características termodinámicas de un área de muestra. Para esto, se utilizó una serie de datos históricos de 1980 a 2019 y 42 transectos móviles nocturnos de temperatura y humedad relativa del aire. Se utilizó el método de regresión polinomial para interpolar estas variables. Los resultados del análisis de variabilidad climática fueron: cantidad equivalente de anomalías de lluvia positivas y negativas en la serie

'Universidade Estadual de Maringá (UEM), Departamento de Geografia, Maringá, Brasil, cminaki@uem.br, https://orcid.org/0000-0002-1581-1303 
histórica, pero de 2013 a 2018 hubo una secuencia de estas anomalías positivas; anomalías negativas de la temperatura media del aire, principalmente en la década de 1980; y reducción de los valores medios anuales de humedad relativa del aire desde 2000 hasta 2019. En cuanto al análisis de los transectos móviles, se observó una celda de calentamiento con valores máximos de diferencia de $6,5^{\circ} \mathrm{C}$ de temperatura y $36 \%$ de humedad en relación con el sus alrededores.

Palabras clave: Variabilidad Climática. Transecto Móvil. Mediciones Termohigrométricas. Características Termodinámicas.

\section{Introdução}

Segundo o Instituto Brasileiro de Geografia e Estatística (IBGE, 2018) há 5.570 municípios no país, e independente do porte populacional são áreas cujas características físicas, ocupacionais e infraestruturais podem contribuir para a configuração de um clima específico. Quando se aborda a formação de um clima no município, o espaço urbano é a dimensão de enfoque nas discussões em escala local, logo, apropriadamente utiliza-se a expressão clima urbano.

Analisar um clima urbano pode levar ao reconhecimento de microclimas, assim como à percepção de que um local integra e assimila o clima regional em todas as suas características. No caso de Maringá, Santos (1996) destacou a importância dos microclimas gerados na área, em função, principalmente, da quantidade de vegetação urbana existente em parques, bosques, canteiros de ruas e avenidas.

Clemente e Suárez-Inclán (2009, p. 132; p. 135) ressaltaram alguns aspectos que configuram o clima urbano como posição topográfica; quantidade de energia processada na cidade; condutividade calorífica dos materiais empregados nos espaços urbanizados; proliferação de superfícies lisas e brilhantes; características das construções, tais como altura, forma e posição; ausência de água, dentre outros.

Muitas vezes, a diversidade desses aspectos instiga 0 pesquisador à determinação do peso ou do grau de influência que cada um possui sobre o clima local. No entanto, isso é de difícil definição, uma vez que a cidade não funciona, a rigor, exatamente do mesmo modo durante todos os dias do ano. Isto é, todos os componentes que a constituem, são influenciados diariamente por mecanismos naturais e pelas consequências dos processos urbano-industriais. Além disso, nem todas as cidades são comparáveis entre si, dificultando a padronização metodológica. O certo é que, quanto mais se conhece a área, mais é possível articular sobre suas particularidades e demandas. 
Maringá localiza-se entre os paralelos $23^{\circ} 15^{\prime}$ e $23^{\circ} 34^{\prime}$ de latitude Sul e as

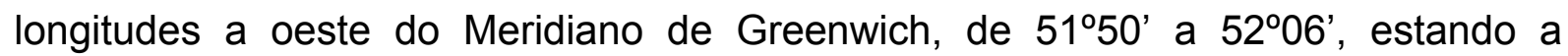
comarca a aproximadamente $23^{\circ} 25^{\prime} 11^{\prime \prime}$ S e $51^{\circ} 57^{\prime} 01^{\prime \prime} \mathrm{O}$. Sua altitude média é de 555 metros, sendo que o município compõe a Mesorregião Norte Central Paranaense (IBGE, 1990, p. 105-106). Possui, atualmente, área total de 487.052 $\mathrm{km}^{2}$, população estimada de 423.666 habitantes (IBGE, 2019), e densidade demográfica de 733.14 hab./km² (IBGE, 2010).

Considerando a importância em conhecer as características termodinâmicas da área, ainda pouco exploradas, buscou-se atender os seguintes objetivos: 19) Caracterizar a variabilidade climática da série histórica de 1980 a 2019; 2) Avaliar os resultados de medidas móveis noturnas de temperatura e umidade relativa do ar, a partir das características gerais da dinâmica observada e da análise sazonal da amostra.

\section{Procedimentos metodológicos}

A pesquisa foi dividida em duas etapas, sendo que a primeira consistiu na análise da série histórica da temperatura do ar e da precipitação de 1980 a 2019 , para compreender a variabilidade climática da área. Na segunda etapa, analisou-se as medidas termohigrométricas, a partir de transectos móveis noturnos para verificar possíveis células de aquecimento em uma área amostral, verificando as características gerais dessa ocorrência e elaborando uma análise sazonal dos episódios. Buscou-se ainda nesta etapa, interpolar os dados com o método da regressão polinomial, para o qual se apresentou separadamente as razões dessa escolha.

\section{a) Variabilidade climática a partir de uma série histórica de dados}

Para a compreensão da variabilidade climática de Maringá foram utilizados os dados da Estação Climatológica Principal de Maringá-PR (ECPM), do período de 1980 a 2019 (somente anos completos). A ECPM localiza-se no interior da Universidade Estadual de Maringá (UEM), sob as coordenadas $23^{\circ} 24^{\prime} 19^{\prime \prime} \mathrm{S}$ e $51^{\circ}$ 55' 58" W, com altitude relativa de $542 \mathrm{~m}$. Esta estação convencional pertence à rede de estações do Instituto Nacional de Meteorologia (INMET), sob o código 83767, sendo que a série histórica selecionada é ininterrupta, não necessitando de preenchimento de falhas de dados. 
Utilizou-se a temperatura média compensada na unidade grau Celsius $\left({ }^{\circ} \mathrm{C}\right)$, e a precipitação total mensal na unidade milímetros $(\mathrm{mm})$ a partir da soma dos valores diários (24h), ambos divulgados pelo INMET. Fez-se o uso da série histórica de mais duas modalidades da temperatura do ar - mínima e máxima -, e da umidade relativa do ar para fins comparativos entre os elementos climáticos.

Calculou-se as anomalias mensais e anuais de precipitação (também denominada chuva) e de temperatura normalizadas pelo desvio padrão médio (Equação 1). Para a análise dos resultados utilizou-se gráficos com a finalidade comparativa.

$$
A C_{\text {mensal }}=\frac{C_{\text {mểs }}-c_{\text {méd mểs }}}{D P_{\text {méd_mês }}}
$$

Em que:

$A C_{\text {mensal }}=$ Anomalia de chuva mensal $(\mathrm{mm})$

$C_{m e ̂ s}=$ Total de chuva verificado no mês $(\mathrm{mm})$

$C_{\text {méd_mês }}=$ Média de chuva do mês $(\mathrm{mm})$ para a série histórica de 1980 a 2019

$D P_{\text {méd_mês }}=$ Desvio padrão mensal médio da chuva $(\mathrm{mm})$ para a série histórica de 1980 a 2019

O mesmo cálculo foi aplicado para as anomalias anuais de chuva, assim como para as anomalias mensais e anuais de temperatura $(A T)$, respeitando-se a substituição dos valores, conforme a escala temporal utilizada (ano ou mês).

Buscou-se também compreender a variabilidade climática por meio das teleconexões com o Oceano Pacífico e o Oceano Atlântico que podem influenciar a área, com base em Biastoch et al. (2009), Bombardi e Carvalho (2010), Bombardi et al. (2013) e Minaki e Montanher (2019).

\section{b) Medidas móveis noturnas de temperatura e de umidade relativa do ar}

Para o levantamento dos dados de temperatura e umidade relativa do ar utilizou-se a metodologia dos transectos móveis noturnos, adaptada de Oke e Maxwell (1975). Selecionou-se um percurso, que abrangeu diferentes áreas do município, em termos de ocupação, quantidade de população e densidade de vegetação. Seu traçado foi iniciado e concluído em áreas de menor ocupação, mais afastadas do centro da cidade, abrangendo cerca de $16 \mathrm{~km}$.

Neste percurso realizado com automóvel à velocidade baixa, um sensor termohigrométrico foi acoplado no interior do veículo com o auxílio de uma haste de bambu estendida desde o chão do carro até um metro acima do vidro do passageiro, 
que em condição de abertura, possibilitou ao sensor o contato com o ar externo. Desta forma, com o equipamento preparado e o automóvel em movimento, os dados foram mensurados a cada 30 segundos, e a duração do percurso foi de aproximadamente 50 minutos.

O registrador utilizado consistiu em um termohigrômetro digital com sensor interno e externo TH-03B, da marca Impac, com precisão de $1^{\circ} \mathrm{C}(+/-)$ para a temperatura e de 5\% (+/-) para a umidade. Este instrumento foi calibrado tendo como parâmetro os termômetros da ECPM. O procedimento para calibração consistiu no acompanhamento de mais de 24 horas de ambos os termômetros. Assim, foram comparados na escala horária, os valores mensurados pelo sensor de temperatura e de umidade utilizados nesta pesquisa, e os termômetros de bulbo seco e de bulbo úmido que compõem o psicrômetro, instrumento mantido no interior do abrigo meteorológico.

Buscou-se condições atmosféricas reconhecidas como ideais para a verificação dos efeitos mais intensos da ilha de calor atmosférica, como dias claros, calmos ou com ventos fracos, "uma vez que mais energia solar é capturada em dias claros, e ventos mais brandos removem o calor de maneira mais vagarosa, fazendo com que a ilha de calor se torne mais intensa" (GARTLAND, 2010, p. 18). Em razão disso, as medições ocorreram sempre às $21 \mathrm{~h}$, cerca de três horas após o pôr do Sol e desprezando-se o horário de verão. O uso dos dados noturnos se justifica pelo fato de que, aproximadamente neste intervalo após o pôr do Sol, já se iniciou o resfriamento da Terra, mas as temperaturas tendem a não registrar mudanças tão significativas, e qualquer diferença observada considerou-se que foi exclusivamente causada pela dinâmica da configuração da cidade.

Durante os transectos, utilizou-se um aparelho móvel receptor de GPS, modelo Etrex Venture HC, da marca Garmin, programado no mesmo intervalo de tempo que o sensor, para obter as coordenadas de cada ponto no sistema Universal Transversa de Mercator (UTM). Ambos os instrumentos funcionaram com o horário padronizado, segundo o fuso oficial de Brasília.

Visando o acompanhamento da variação dos elementos térmico e higrométrico no intervalo das $21 \mathrm{~h}$ às $22 \mathrm{~h}$, verificou-se o banco de dados da estação de superfície automática da ECPM (código 86899), instalada junto à estação convencional, e operando desde 2006.

Com os dados da estação automática, considerou-se que se houvesse uma variação de temperatura na ECPM maior que $1,5^{\circ} \mathrm{C}$ no intervalo das $21 \mathrm{~h}$ às $22 \mathrm{~h}$, a 
diferença térmica obtida no transecto não poderia ser considerada resultante de uma célula de aquecimento na área. Esse limiar foi definido, pois abrange situações em que a modificação das condições atmosféricas durante o transecto, podem ser atribuídas à atuação dos diferentes tipos de tempo nos locais de coleta dos dados.

Por outro lado, o registro de ventos superiores a 2,0 m/s indicaria situação de instabilidade provocada pela circulação regional, configurando o desfazimento da ilha de calor, tendo em vista que, Gartland (2010) ressaltou a possibilidade de ocorrência destas sob ventos de intensidade fraca. Velocidade inferior à estimada por Oke e Hannel (1970), que nas primeiras pesquisas em que se estabelecia a velocidade crítica do vento que elimina os efeitos da ilha de calor, citaram o intervalo de 6 a $8 \mathrm{~m} / \mathrm{s}$, para cidades com 300.000 habitantes. As informações dos ventos foram trabalhadas no software WRPLOT View - Wind Rose Plots for Meteorological Data, versão freeware (LAKES ENVIRONMENTAL, 2018).

As medições ocorreram em 42 noites, no período de março de 2016 a abril de 2017, predominando dias úteis. Não houve uma distribuição igualitária de transectos nas quatro estações do ano. A Figura 01 apresenta o traçado do percurso realizado em Maringá, bem como a localização da ECPM, na qual funciona a estação convencional e a automática no mesmo perímetro.

Figura 01 - Localização do município de Maringá, da ECPM e da área selecionada para o percurso dos transectos móveis (extensão norte-sul)

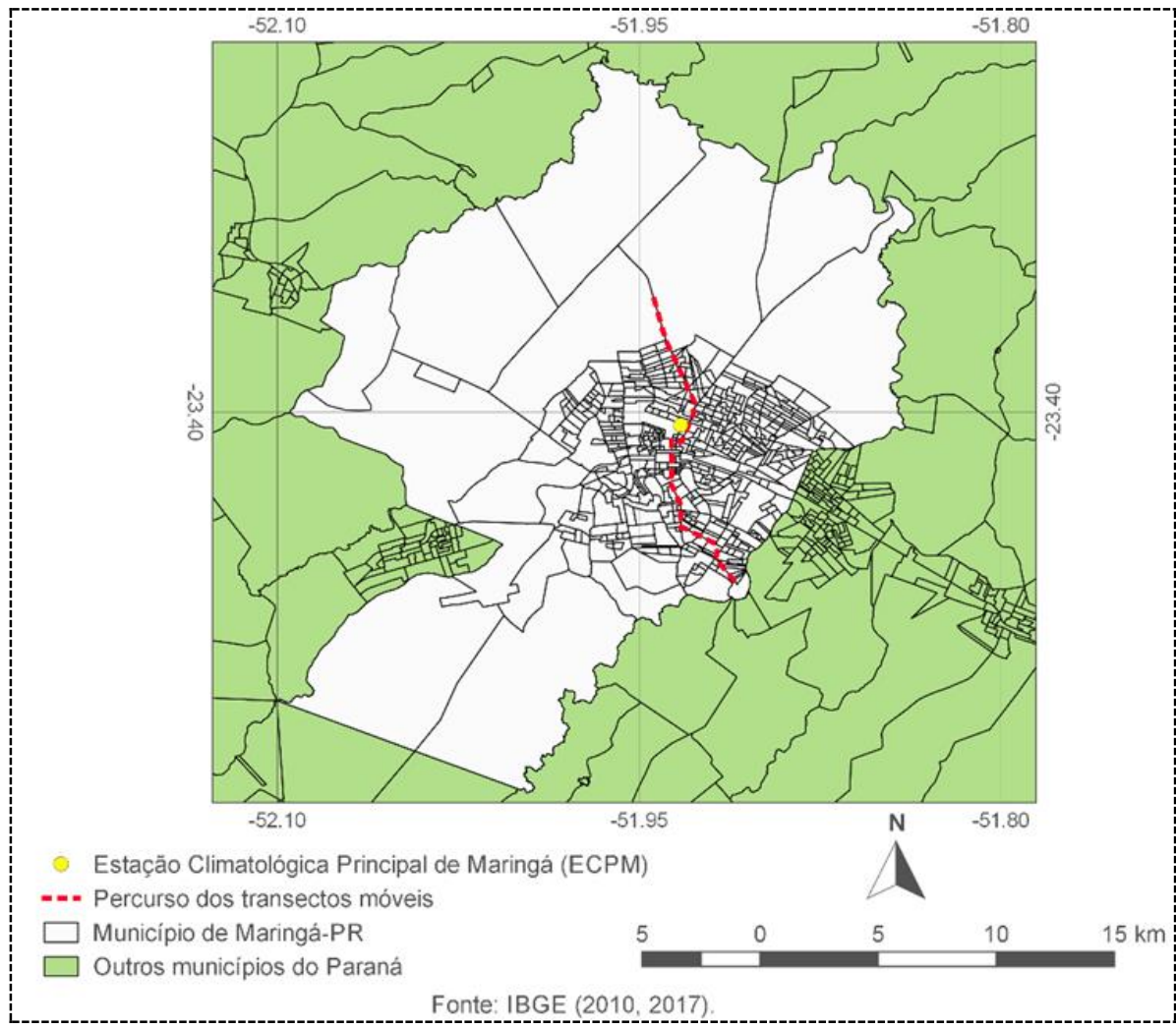

Fonte: Elaboração da autora. 


\section{c) Escolha do método de interpolação}

A escolha pela interpolação utilizando o método de regressão polinomial deuse pelas características de distribuição espacial da amostragem, realizada em sentido aproximadamente Norte-Sul. Objetivou-se tecer considerações apenas sobre a área amostral, evitando-se analisar regiões mais distantes e extremidades do mapa, gerando-se uma grade regular pela função polinomial.

$\mathrm{Na}$ climatologia geográfica nacional é comum o uso do método da krigagem na espacialização das ilhas de calor (AMORIM, 2019), considerando que o software Surfer, foi bastante utilizado na geração de isolinhas, por meio de configurações automáticas. Mesmo nos casos em que são realizados mais de um percurso para os transectos móveis, ampliando o tamanho e melhorando a distribuição amostral, ainda é possível se deparar com a falta de representatividade espacial, devido à alta variabilidade dos elementos climáticos nesta escala de detalhe. A variabilidade em escala intraurbana, portanto, é mais um aspecto que inviabiliza o uso da krigagem a partir de dados adquiridos ao longo de transectos.

O método da krigagem (ou krigeagem) foi desenvolvido para resolver problemas de mapeamento geológico, sendo hoje difundido para muitos campos correlatos (CAMARGO et al., 2004, p. 103), como a climatologia. Trata-se de "um conjunto de técnicas de estimação e de predição de superfícies baseada na modelagem da estrutura de correlação espacial" (CAMARGO et al., 2004, p. 90). Neste procedimento geoestatístico, diferente de outros métodos de interpolação, há a estimativa de uma matriz de covariância que irá determinar os pesos atribuídos a diferentes amostras (CAMARGO et al., 2004, p. 91). Essa complexidade aliada aos diferentes tipos de krigagem demonstram o quanto se deve conhecer de Geoestatística para estimar, com precisão, todos os parâmetros necessários e não simplificar demais o seu uso.

Pode-se mencionar a aplicação da regressão polinomial em trabalhos como os de Romero et al. (2013), Gomes et al. (2015) e Reis et al. (2016). Nestas pesquisas, os autores estimaram variáveis climáticas nas seguintes situações: ausência de dados de estações meteorológicas; irregularidade de distribuição dessa infraestrutura no país; e dificuldade de se obter séries temporais ou até de reconhecer a qualidade dos dados existentes.

Após definida a escolha, os dados mensurados foram trabalhados no software QGIS (QGIS DEVELOPMENT TEAM, 2009). Cada episódio foi transformado em 
arquivo matricial (também denominado raster), utilizando-se interpoladores simples da ferramenta Regressão Polinomial. Estes interpoladores - superfície plana simples e bilinear - foram escolhidos conforme o conjunto de dados diários, evitando o uso de polinômios de maior ordem para que as matrizes geradas não criassem feições espúrias.

Portanto, apesar de se tratar de um percurso que abrangeu desde áreas rurais próximas até a área central de Maringá, a distribuição espacial da amostra é insuficiente para que se amplie os resultados para toda a área urbana. Há outras formas de modelar a variabilidade espacial, mas houve preferência pela suposição implícita neste interpolador por superfície de tendência. Isto é, na caracterização do fenômeno de estudo, predomina a variação em larga escala e não os efeitos puramente locais (CAMARGO et al., 2004, p. 80).

A análise sazonal dos dados dos transectos móveis, ocorreu considerando o verão, representativo dos meses de Janeiro, Fevereiro e Março (JFM), outono representativo dos meses de Abril, Maio e Junho (AMJ), inverno representativo dos meses de Julho, Agosto e Setembro (JAS), e primavera representativa dos meses de Outubro, Novembro e Dezembro (OND). Todas as vezes em que valores médios dos transectos móveis foram apresentados por estação, não se utilizou os dados das duas medições ocorridas no ano de 2017, para facilitar o agrupamento dos resultados sazonais para o ano de 2016.

\section{Análise do clima de Maringá-PR sob o enfoque da variabilidade (1980 a 2019)}

Com pluviosidade anual média de 1699 mm e desvio padrão de 299,4 mm, Maringá possui valores extremos de chuva, abaixo e acima da média, que se destacam na série histórica, cujos dados foram apresentados na forma de anomalias na Figura 02. No período, quando ocorreu anomalia de chuva positiva $(A C+)$, em geral, verificou-se anomalia de temperatura negativa (AT-), com exceções como em 1998, 2002 e principalmente, a partir de 2014 quando esse padrão foi modificado. Isto é, na ocorrência de $A C+$ também se verificou anomalia de temperatura positiva $(A T+)$. Quanto ao padrão de AC-, houve variações, mas os maiores valores desse tipo de anomalia foram acompanhados de AT-.

O ano de 1988 foi o mais seco dessa série histórica, havendo um episódio de El Niño forte em 1987/88 e um La Niña moderado em 1988/89, segundo a classificação de intensidade do CPTEC/INPE. Em 1988, os dados do Índice Oscilação Sul (IOS) e da Temperatura da Superfície do Mar (TSM) indicaram um 
verão em transição de El Niño para a condição de neutralidade, e um outono de transição da neutralidade climática para a condição de La Niña. Já o ano de 2015 foi o mais chuvoso da série, registrando $2724 \mathrm{~mm}$, sendo os meses de junho e agosto, os únicos com média mensal de precipitação inferior à média da série histórica. Em 2015, o IOS esteve negativo em quase todos os meses, e a TSM obteve anomalias positivas acima de $2^{\circ} \mathrm{C}$ desde setembro (Figura 03 ).

Figura 02 - Anomalias de chuva (AC+; AC-) e de temperatura (AT+, AT-) em Maringá-PR (1980 a 2019)

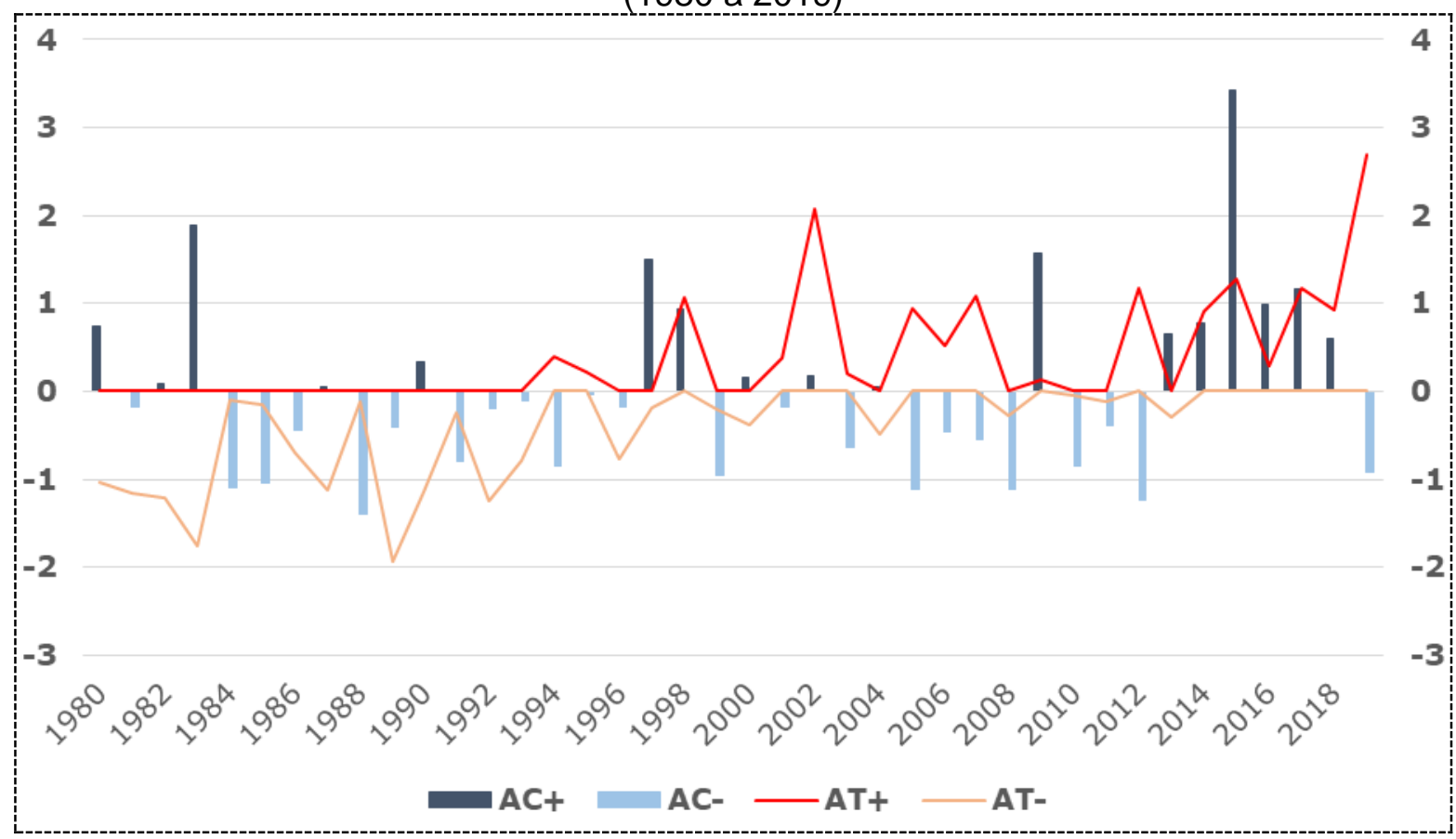

Fonte dos dados: INMET.

Figura 03 - Anos extremos para a precipitação em Maringá-PR. a) 1988 e b) 2015: Dados de anomalias mensais positivas e negativas de Temperatura da Superfície do Mar (TSM) na região Niño 3.4 (ATSM+, ATSM-); IOS; Anomalia de Chuva (AC) em Maringá-PR; Anomalia de Temperatura (AT) em Maringá-PR

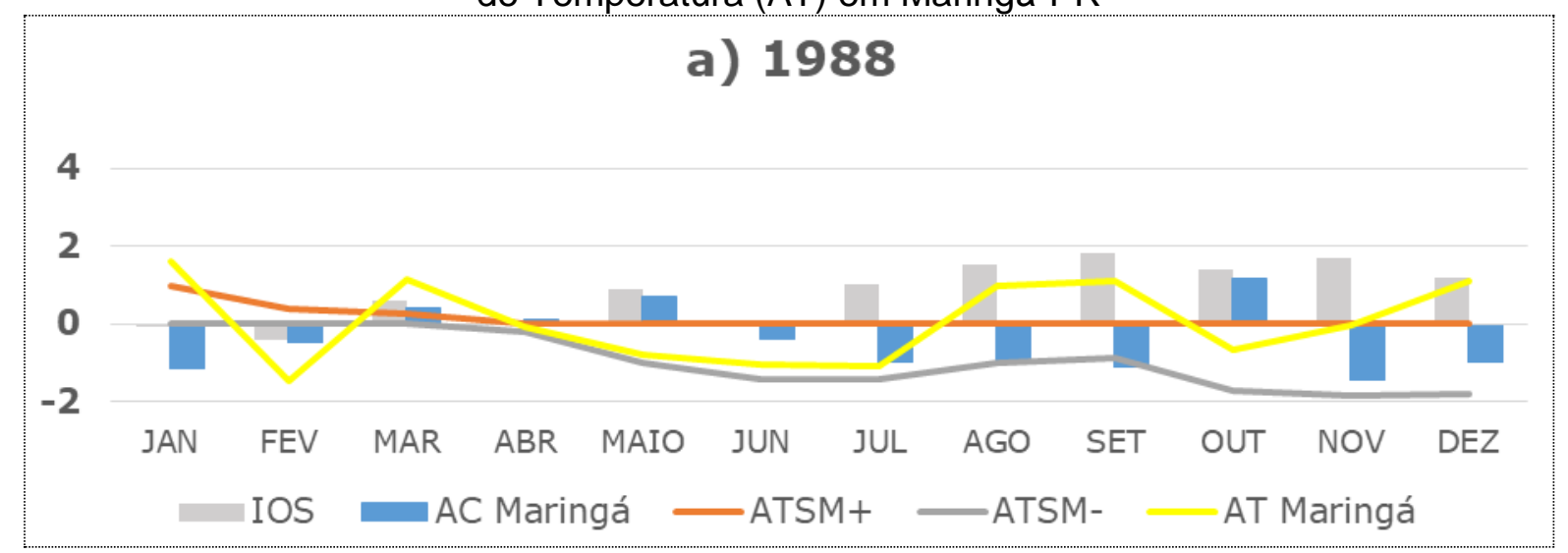




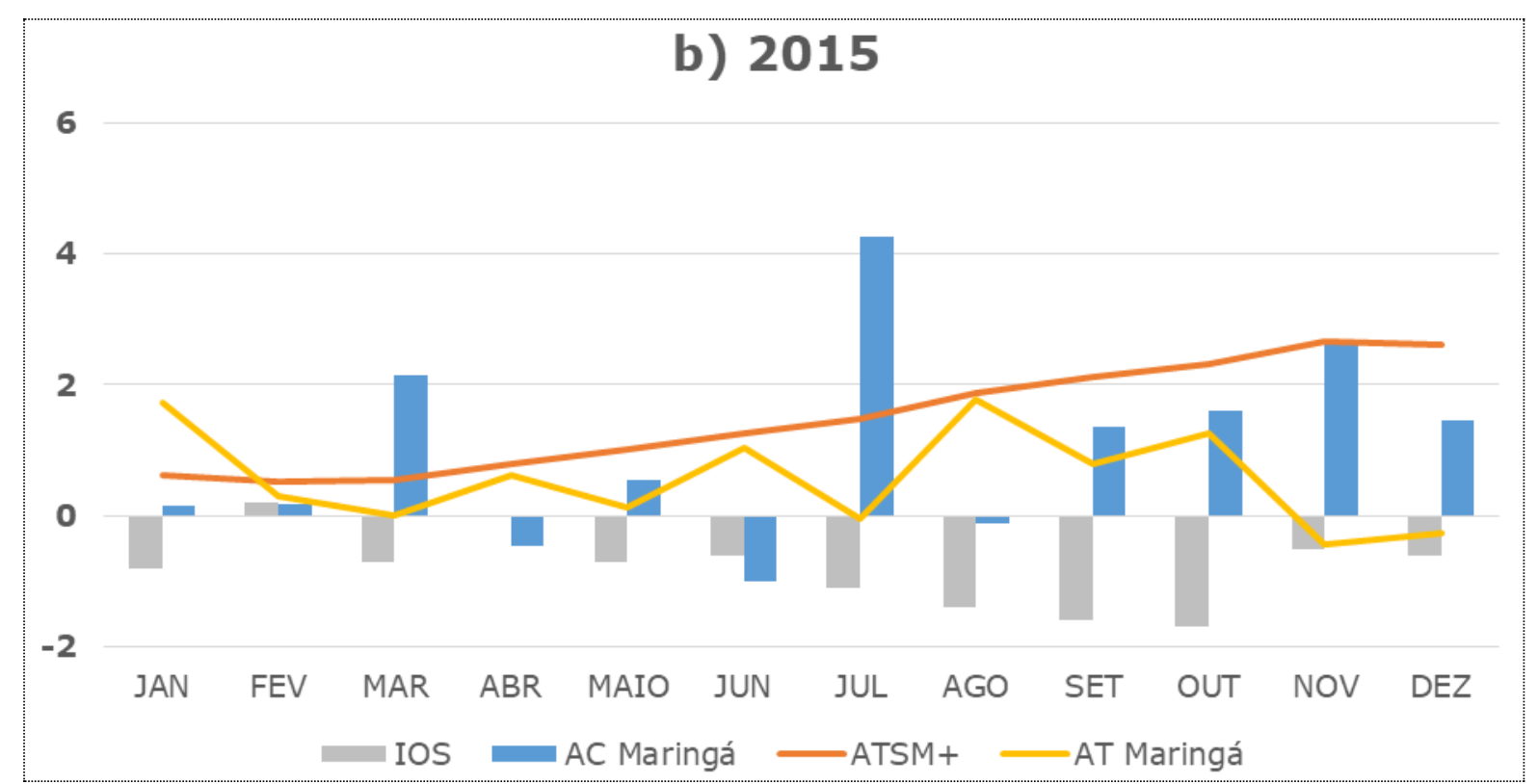

Fonte dos dados: CPC/NOAA; INMET.

Para os meses de 1988 observa-se o predomínio de IOS+ e AC- para Maringá. A AT para Maringá variou regularmente entre positivo e negativo, enquanto houve o predomínio de ATSM-. Para os meses de 2015 destaca-se AC+ e de ATSM+. O IOS, em geral, foi positivo.

A maioria dos transectos móveis noturnos foi realizada no ano de 2016 , caracterizado por 1996,1 mm de pluviosidade, sendo o $6^{\circ}$ ano mais chuvoso da série histórica de 40 anos. A temperatura média foi $22,5^{\circ} \mathrm{C}$, sendo $014^{\circ}$ ano mais quente, enquanto a temperatura média mínima foi $17,9^{\circ} \mathrm{C}$ e a média máxima atingiu $28,7^{\circ} \mathrm{C}$.

Pela Figura 04 retoma-se a análise de toda a série histórica, para compreender algumas particularidades do ano de 2016. A umidade relativa do ar decresceu em todos os períodos. A precipitação decresceu até 2009, aumentando significativamente entre 2000 a 2018. A temperatura do ar aumentou sobretudo entre 1990 a 2009, tendo um aumento menor no último período. O mesmo se aplica à temperatura máxima, e dentre as temperaturas, a medida de temperatura mínima é a que teve uma dinâmica diferenciada, aumentando bastante entre 1990 a 2009, mas tendo a queda mais significativa no último período. 
Figura 04 - Síntese da variação $(\Delta)$ das médias, por período, de precipitação $(\mathrm{mm})$, de três modalidades de temperatura do $\operatorname{ar}\left({ }^{\circ} \mathrm{C}\right)$ e da umidade relativa do ar (\%) (1ํ período: décadas 1980/1990; 2o período: décadas de 1990/2000; 3ํperíodo: décadas de 2000/2010)

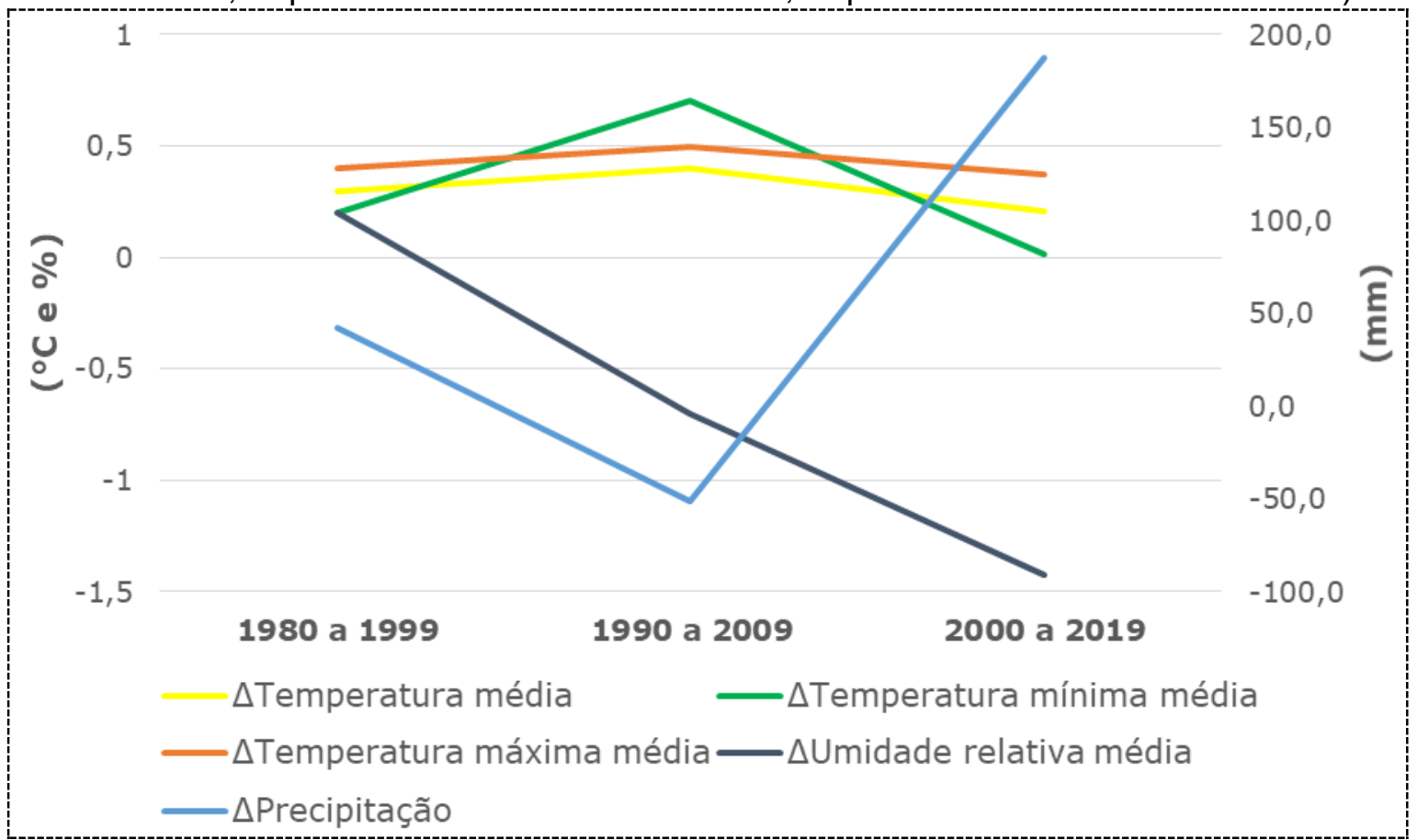

Fonte dos dados: INMET.

Pela Figura 04, considerando valores médios, o ano de 2016 consta no período de maior volume de precipitação, queda mais acentuada da umidade relativa do ar e da temperatura mínima, além de queda da temperatura máxima e da temperatura. Este ano iniciou-se chuvoso dando continuidade aos grandes volumes observados no último quadrimestre de 2015, resultando em um acumulado de 6 meses de precipitação (SOND/2015 a JF/2016) de 2049,5 mm. A variabilidade do regime higrométrico da série histórica caracteriza-se pelos maiores desvios padrão no inverno. Em 2016, a umidade relativa do ar obteve a média de $65,4 \%$, sendo o $4^{\circ}$ ano menos úmido da série histórica.

A temperatura mínima média embora tenha aumentado no período de 2000 a 2009, diminuiu no último período em análise. Sua amplitude na série histórica correspondeu a $2,2^{\circ} \mathrm{C}$ e entre o verão e o inverno foi de $5,3^{\circ} \mathrm{C}$.

Minaki e Montanher (2019, p. 278-279) não encontraram correlação significativa para o período de 1980 a 2016 entre os eventos de ENOS e as anomalias de precipitação em Maringá, no entanto, quando as correlações de Pearson e de Kendal foram aplicadas mês a mês, demonstrou-se que a influência do El Niño no maior volume de precipitação no município é representativa em meses do outono e da primavera. No entanto, o ENOS não é a única teleconexão que influencia a variabilidade climática interanual e intrasazonal de Maringá. 
O quadrante em que a área se localiza é de ocorrência dos padrões de anomalia de TSM do Atlântico Sul. Chaves (2011) buscou identificar e descrever se os principais padrões associam-se com a convecção de verão da América do Sul, utilizando-se de métodos estatísticos e uma série histórica de anomalias de TSM e de ROL, ambas do Atlântico Sul, de 1979 a 2001.

Pelo uso da Análise de Componentes Principais (ACP), foram determinados três modos das anomalias de TSM sobre o Atlântico Sul, e a autora concluiu que em dois modos há acentuada variabilidade interanual, e um deles está associado ao El Niño-Oscilação Sul (ENSO).

O modo do Dipolo Subtropical da América do Sul (DSAS) possui duas fases de sinais opostos. $\mathrm{Na}$ fase positiva as anomalias são positivas à sudoeste do Atlântico Sul, e negativas à nordeste; enquanto na fase negativa ocorre o inverso. Em anos de fase negativa do DSAS, há um aumento das chuvas no Sul do Brasil, enfraquecimento da Zona de Convergência do Atlântico Sul (ZCAS) e possível seca na região Sudeste (BOMBARDI et al., 2011, 2013). Houve um aumento dos eventos negativos de DSAS a partir dos anos de 1981/82 até 2011, acompanhado de redução da variabilidade do dipolo, mudanças estas associadas às alterações nos campos de ventos sobre o Atlântico Sul (ANDRADE, 2015, p. 39) devido à migração da Alta Subtropical do Atlântico Sul (ASAS) para norte, já que o DSAS é gerado por essas migrações do anticiclone (BIASTOCH, 2009).

As considerações obtidas sobre a variabilidade climática de Maringá, a partir da série histórica de dados de 1980 a 2019, de temperatura do ar e de precipitação foram:

- Ao se quantificar os episódios de anomalias positivas e negativas de chuva, houve uma quantidade equiparada entre ambos. No entanto, ao se considerar a escala temporal, de 2013 a 2018, houve uma sequência de anomalias positivas de chuva. Com relação à temperatura, houve mais irregularidade na alternância entre as anomalias, quando comparada à chuva. De 1980 a 1993 houve uma sequência de anomalias negativas, enquanto que de 2014 a 2018 houve uma sequência de anomalias positivas de temperatura, sendo a de 2019, a maior de toda a série. Portanto, os últimos anos (2014 a 2018) destacaram-se por IAC e IAT positivos concomitantemente;

- Além dos sistemas atmosféricos atuantes característicos da circulação regional, as teleconexões também explicam possíveis influências sobre a quantidade 
de chuva e a temperatura média da área, sobretudo na escala intrasazonal, podendo-se citar tanto o oceano Pacífico quanto o oceano Atlântico.

\section{Variabilidade da temperatura e da umidade relativa do ar nos transectos móveis noturnos}

Se por um lado, a análise da variabilidade climática da série histórica possibilita a identificação de oscilações periódicas nas dinâmicas dos valores extremos dos elementos, os registros pontuais proporcionam uma caracterização da variabilidade local.

Em geral, os pontos iniciais do transecto em comparação aos pontos finais, obtiveram valores menores de temperatura e maiores de umidade relativa do ar. No entanto, a região de proximidade do Córrego Moscados na Zona Sul, que não corresponde no trajeto à um ponto inicial ou final, foi a que registrou os menores valores de temperatura e os maiores valores de umidade relativa do ar. Ressalta-se que essa região caracteriza-se pela diminuição altimétrica em relação aos demais pontos dos transectos, e pelo Córrego Moscados (Figura 05). A diferença termohigrométrica deste ponto com os demais foi maior nos dias com presença do ar polar e predomínio de tempo anticiclônico.

Figura 05 - Hipsometria de Maringá-PR

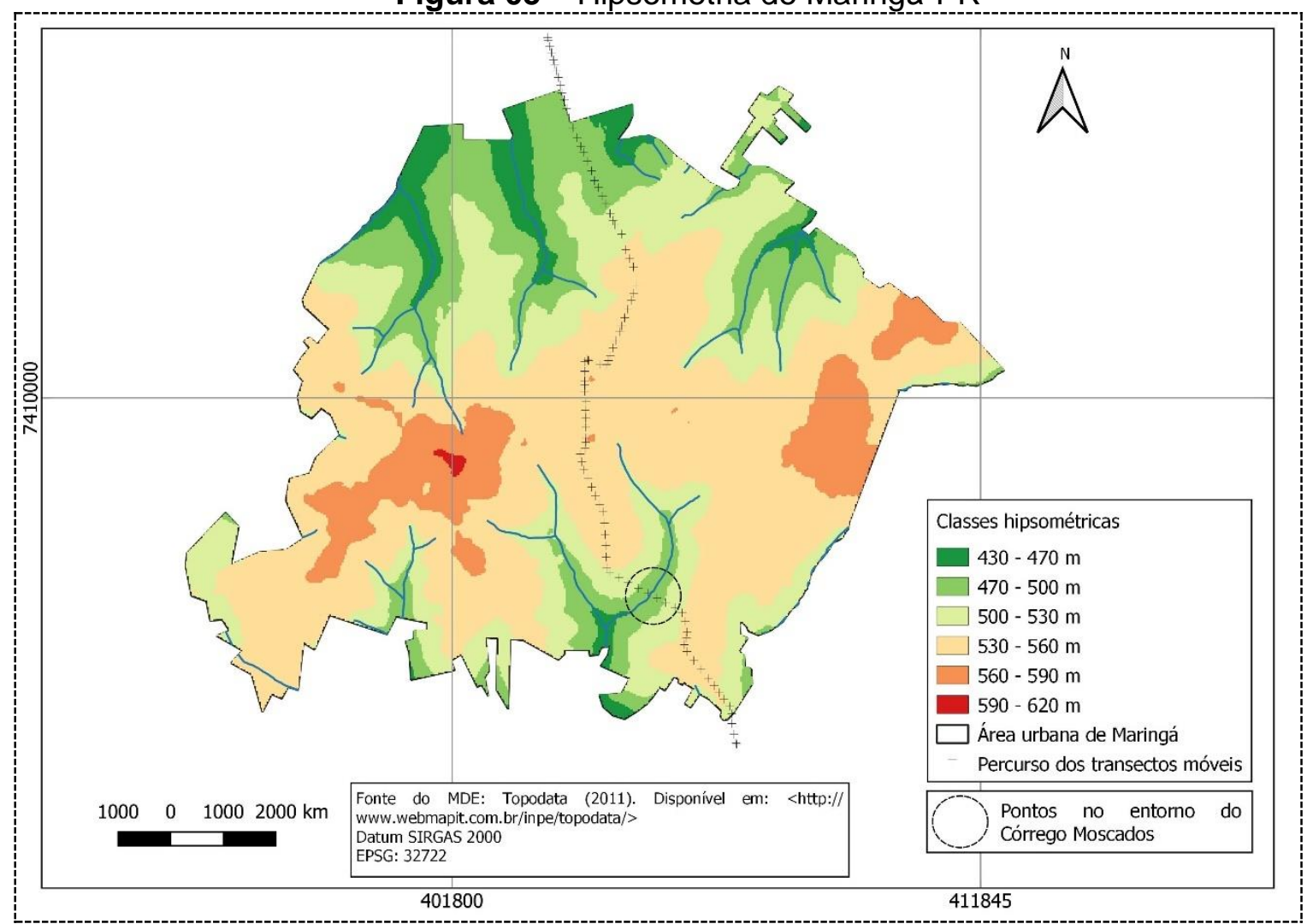

Fonte: Elaboração da autora. 
Pela hipsometria de Maringá (Figura 05) observa-se amplitude altimétrica de até $190 \mathrm{~m}$, no entanto, nas áreas abrangidas pelo percurso esse valor alcançou 120 $\mathrm{m}$. Os pontos iniciais no setor norte da cidade caracterizaram-se pelas altitudes mais baixas, assim como os pontos de registro na zona sul. A nível de município, há o predomínio do intervalo altimétrico de 530 a $560 \mathrm{~m}$, acompanhado da característica de relevo plano. Em geral, não há diferenças altimétricas na área amostral que caracterizem este estudo como topoclimático, estando as diferenças muito mais relacionadas ao tipo de cobertura e à proximidade com corpo d'água.

As matrizes (rasters) geradas representam diferenças significativas de até $6,5^{\circ} \mathrm{C}$ e $36 \%$. A Figura 06 traz isotermas representativas de condições homogêneas e com a segunda maior diferença térmica obtida no transecto.

Figura 06 - Comparação entre episódios utilizando intervalos padronizados para a temperatura do ar. A: Episódio do dia 21/03/2016, com 0,9ํㅡ C de diferença obtida. B: Episódio do dia 28/08/2016, com 6,4 $\mathrm{C}$ de diferença obtida no transecto

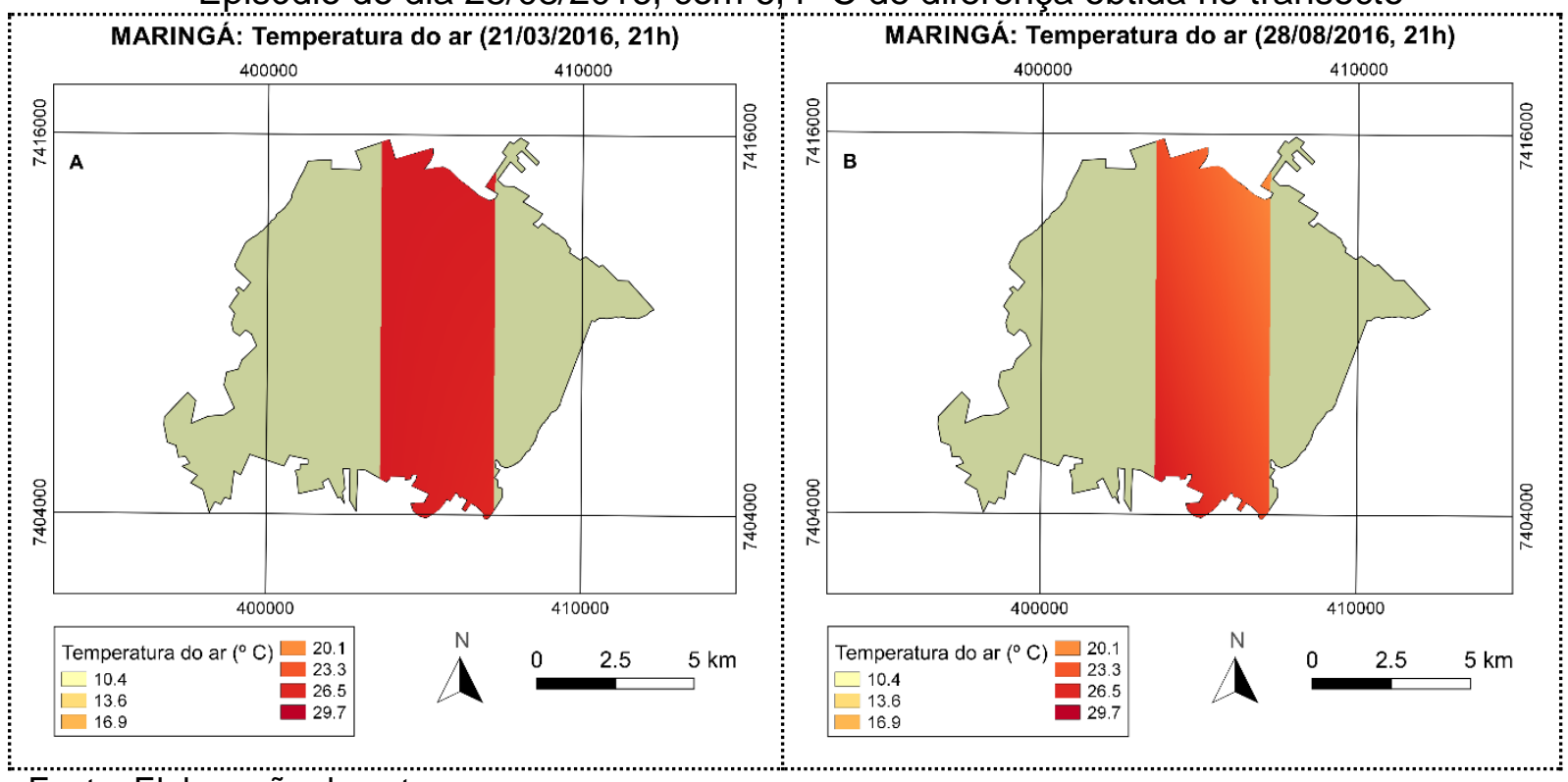

Fonte: Elaboração da autora.

Observa-se pela Figura 06A que o dia 21/03/2016 registrou maior temperatura durante o transecto do que a representada na Figura 06B, no entanto, este elemento praticamente não variou ao longo do percurso. Observou-se nebulosidade durante o percurso e o sistema atmosférico atuante consistiu em uma frente fria estacionária. Situação oposta ocorreu no episódio do dia 28/08/2016 (Figura 06B), em que se observou a proximidade de uma frente fria sobre a região, mas sem a interferência sobre os resultados.

A extensão do centro da cidade até áreas do contorno Sul metropolitano de Maringá teve temperaturas mais significativas e umidades mais baixas. Observou-se 
que, em condições sinóticas de tempo anticiclônico, estas células de aquecimento sobretudo nas áreas mais centrais foram ressaltadas, e os pontos próximos à Unidade de Pronto Atendimento (UPA) Zona Sul, por onde passa o córrego dos Moscados (Figura 05), configuraram-se como os mais frios durante a atuação do ar polar.

Nos dias mais quentes de transecto, esta configuração não foi alcançada na mesma magnitude. Quanto às diferenças higrométricas, as maiores foram observadas nos episódios de muita nebulosidade, devido principalmente à presença de sistemas de baixa pressão na região ou em sua proximidade, responsáveis pela variação do tempo ao longo do dia. No período noturno, enquanto algumas áreas estavam mais secas, outras devido à presença de maior quantidade de vegetação $\mathrm{e}$ de corpos d'água, tiveram seus valores de umidade mais altos.

$\mathrm{Na}$ Figura 07 constam duas matrizes com episódios contrastantes em termos de diferença higrométrica, referindo-se ao episódio mais e menos representativo. No dia 08/11/2016 (Figura 07A), um cavado influenciou a região reduzindo os valores da diferença termohigrométrica entre os pontos, verificando-se nebulosidade e ventos a $1 \mathrm{~m} / \mathrm{s}$ do quadrante $\mathrm{S}$. No dia 24/04/2017 (Figura 07B), já com a proximidade do ar polar frio, verificou-se alta diferença higrométrica, registrando o ponto mais úmido o valor de $90 \%$ (setor norte), enquanto o ponto menos úmido registrou $54 \%$.

Figura 07 - Comparação entre episódios utilizando intervalos padronizados para a umidade relativa do ar. A: Episódio do dia 08/11/2016, com 4\% de diferença obtida. B: Episódio do dia $24 / 04 / 2017$, com $36 \%$ de diferenca obtida no transecto



Fonte: Elaboração da autora. 
Ao se comparar os dados de temperatura às $21 \mathrm{~h}$ e às $22 \mathrm{~h}$ da estação automática, com os dados dos transectos móveis, não se verificou variação superior a $1,5^{\circ} \mathrm{C}$, tornando as diferenças obtidas em campo proficientes nesta pesquisa.

Pode-se concluir, a partir da influência de uma dinâmica combinada entre sistemas atmosféricos atuantes e características da cobertura do terreno sobre a configuração de ilhas de calor e de ilhas secas, que:

- Em situações com predomínio do ar polar, a presença de vegetação e de corpos d'água são determinantes para a temperatura e para a umidade relativa do ar;

- Com a proximidade ou a saída do sistema frontal na área, houve o alcance de diferenças altas entre os elementos;

- O vento gerado pelas variações de temperatura e de pressão atmosférica no ambiente, mesmo em velocidades baixa, como $1 \mathrm{~m} / \mathrm{s}$, desconfiguram as condições para a formação de células de aquecimento.

\section{Análise sazonal e dos dados médios dos transectos móveis noturnos}

Com relação às particularidades sazonais dos dados dos transectos móveis (Tabela 01), o verão de 2016 obteve maior pluviosidade entre todas as outras estações, ultrapassando a média da série histórica. Conforme a Figura 02, as anomalias de temperatura e de chuva foram positivas, e essa configuração já se observou em 2015, indicando modificações nesse padrão, a partir de 2017. A maior constância de vapor d'água na atmosfera favoreceu a elevação da umidade relativa do ar, sobretudo nas áreas mais vegetadas, ocorrendo contrastes significativos com áreas menos vegetadas. Pela Tabela 01 observa-se que, nesta estação, houve a maior média de umidade relativa do ar tanto nos transectos móveis quanto na série histórica.

Tabela 01 - Dados médios dos transectos móveis noturnos (TN) e da série histórica (SH) de 1980 a 2019 da temperatura (T), da umidade relativa do ar (UR) e da precipitação (P), com desvios padrão (DP) médios, por estação

\begin{tabular}{c|c|c|c|c|c|c|c|c}
\multirow{2}{*}{ DADOS } & \multicolumn{2}{c}{ VERÃO } & \multicolumn{2}{c}{ OUTONO } & \multicolumn{2}{c}{ INVERNO } & \multicolumn{2}{c}{ PRIMAVERA } \\
\cline { 2 - 9 } & $\mathrm{TN}$ & $\mathrm{SH}$ & $\mathrm{TM}$ & $\mathrm{SH}$ & $\mathrm{TM}$ & $\mathrm{SH}$ & TM & $\mathrm{SH}$ \\
\hline $\mathrm{T}\left({ }^{\circ} \mathrm{C}\right)$ & 26,4 & 24,7 & 21,6 & 20,3 & 19,2 & 20,2 & 25,7 & 24,1 \\
\hline $\mathrm{DP}\left({ }^{\circ} \mathrm{C}\right)$ & 0,1 & 0,7 & 0,8 & 1,2 & 0,5 & 1,7 & 0,3 & 0,9 \\
\hline $\mathrm{UR}(\%)$ & 66,8 & 73,5 & 63,8 & 71,7 & 57,5 & 62 & 59,1 & 67,3 \\
\hline $\mathrm{DP}(\%)$ & 1,5 & 4,9 & 3,6 & 5,5 & 3,2 & 7,3 & 2,8 & 5,6 \\
\hline $\mathrm{P}(\mathrm{mm})$ & 905,6 & 572,9 & 451,1 & 354,6 & 248,6 & 257,7 & 390,8 & 513,9 \\
\hline $\mathrm{DP}(\mathrm{mm})$ & 174,2 & 88,7 & 90,9 & 85,7 & 54,7 & 73 & 89,4 & 87
\end{tabular}


Somente a temperatura média obtida nos transectos de inverno foi inferior à da média da série (Tabela 01), demonstrando o incremento do calor produzido na cidade. A umidade relativa do ar média registrada pelos transectos foi inferior em relação à média da série, em todas as estações. Se, por um lado, o volume elevado de precipitação induz a ideia de que a umidade correspondente deverá ser alta, por outro, é necessário ressaltar, pelo menos duas situações.

A primeira diz respeito à quantidade de dias consecutivos sem chover, ou seja, da mesma forma que a precipitação tende a elevar a umidade relativa do ar, o seu decréscimo é esperado após a passagem da chuva e um período de estiagem. Verificou-se, com exceção da primavera, dias consecutivos sem chuva nas demais estações, alcançando-se o máximo de 29 dias. A segunda é o fato de que o valor de umidade relativa do ar também é também influenciado pelos processos de evaporação e transpiração. Se, por razões como a retirada de árvores e a impermeabilização do solo, esses dois processos são reduzidos, há uma influência sobre a quantidade de vapor d'água presente na atmosfera.

Sobre a possibilidade de outros fatores interferirem neste índice de umidade, além da precipitação, o maior desvio padrão médio da série histórica da umidade relativa do ar foi registrado no inverno, no entanto, o maior desvio padrão médio da precipitação foi registrado no verão. Logo, ambos interagem em suas dinâmicas, mas possuem diferentes mecanismos de configuração.

A temperatura média dos transectos esteve abaixo da registrada pela série histórica no inverno, destacando-se também os maiores desvios nas duas estações mais secas. A diminuição da temperatura no outono-inverno, devido às entradas mais constantes do ar polar pode ser minimizada nos ambientes mais construídos, com maiores fluxos de pessoas e de automóveis, e mais suscetíveis aos materiais que absorvem radiação solar. Neste caso, ofertar maior potencial de aquecimento é um aspecto positivo para áreas que comumente são avaliadas pelo prejuízo causado pelas ilhas de calor. Portanto, o potencial de aquecimento de um setor, como o que abrange as áreas centrais de Maringá, é um indicador dependente da sazonalidade, podendo ser benéfico ou prejudicial à população. A dualidade também é válida para o potencial de arrefecimento das áreas como as rurais próximas, identificadas no percurso.

Durante os transectos, a condição de calmaria predominou $(28,57 \%) \mathrm{em}$ conjunto com ventos de leste $(E)$, sendo o vetor resultante com direção de $82^{\circ}$ e velocidade média de 1,52 m/s (Figura 08A). Os anticiclones Alta Subtropical do 
Atlântico Sul (ASAS) e o Migratório Polar são influências regionais que trazem ventos de leste/nordeste (GRIMM, 2009, p. 263) e de sudeste (SE), respectivamente. Conforme se observa pela Figura 05 , não há predomínio de altitudes elevadas em Maringá, restringindo o papel dos ventos aos efeitos mais fisiológicos, de sensação térmica e higrométrica, verificando-se efeitos topográficos locais em áreas de baixada e áreas cobertas por vegetação de grande porte.

Figura 08 - Ventos nos transectos móveis. A: Percentual da direção dos ventos; B: Episódio com registro de calmaria; C: Episódio com registro de ventos



Fonte: Elaboração da autora.

Os ventos de leste foram registrados, principalmente durante o outonoinverno, sendo o inverno a época em que a ASAS mais se aproxima do continente (GRIMM, 2009, p. 263). Os ventos de S e de SE incidiram principalmente nos transectos de inverno, enquanto os de SW ocorreram mais nos transectos realizados na primavera.

No episódio com a segunda maior amplitude térmica, $28 / 08\left(6,4^{\circ} \mathrm{C}\right.$, Figura 06B), verificou-se condição de calmaria (Figura 08B). Nos dias em que na ECPM registrou-se ventos de $3 \mathrm{~m} / \mathrm{s}$, as diferenças alcançadas no mesmo horário dos transectos foram: $2,1^{\circ} \mathrm{C} / 11 \%$ (Figura $08 \mathrm{C}$ ); $3,9^{\circ} \mathrm{C} / 19 \%$ e $3,3^{\circ} \mathrm{C} / 9 \%$. Notou-se que episódios com baixa amplitude térmica não necessariamente tiveram o registro de ventos.

A ocorrência de ventos durante as mensurações pode levar ao desfazimento da ilha de calor, a partir da homogeneização das condições do tempo na área 
observada, como se observa na Figura 08C em comparação à Figura 08B, em que houve calmaria. Há uma redução da grandeza inversamente proporcional que é típica dos elementos.

Por fim, o Gráfico 01 traz a representação dos dados da temperatura por episódio, incluindo também o desvio padrão. Realizou-se o mesmo procedimento para a umidade relativa do ar e o resultado consta no Gráfico 02.

Gráfico 01 - Amostra da temperatura do ar nos transectos. A: Temperatura média do transecto, temperaturas mínima e máxima observadas em cada episódio. B: Desvio padrão médio observado em cada episódio do transecto

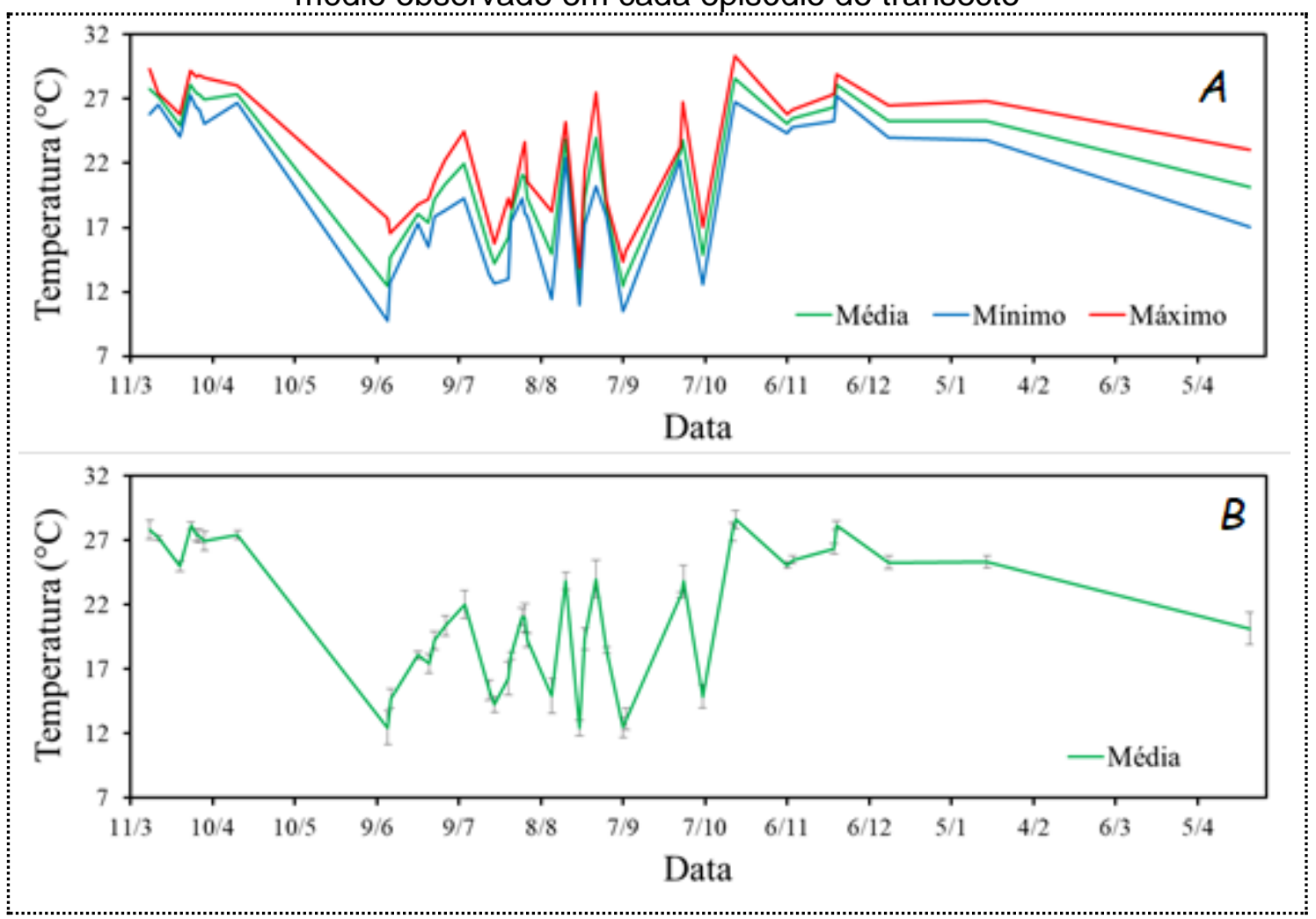

Fonte: Elaboração da autora.

No Gráfico 01 é possível visualizar não só a variação térmica de toda a amostra, como a variação diária. No primeiro caso, as medições de outono-inverno remeteram as linhas do gráfico $A$ à descenderem em comparação aos episódios realizados nas estações opostas. No segundo caso, nota-se em análise diária, que as medições de outono-inverno tiveram os maiores desvios-padrão. 
Gráfico 02 - Amostra da umidade relativa do ar nos transectos. A: Umidade relativa média do transecto, umidades mínima e máxima observadas em cada episódio. B: Desvio padrão médio observado em cada episódio do transecto

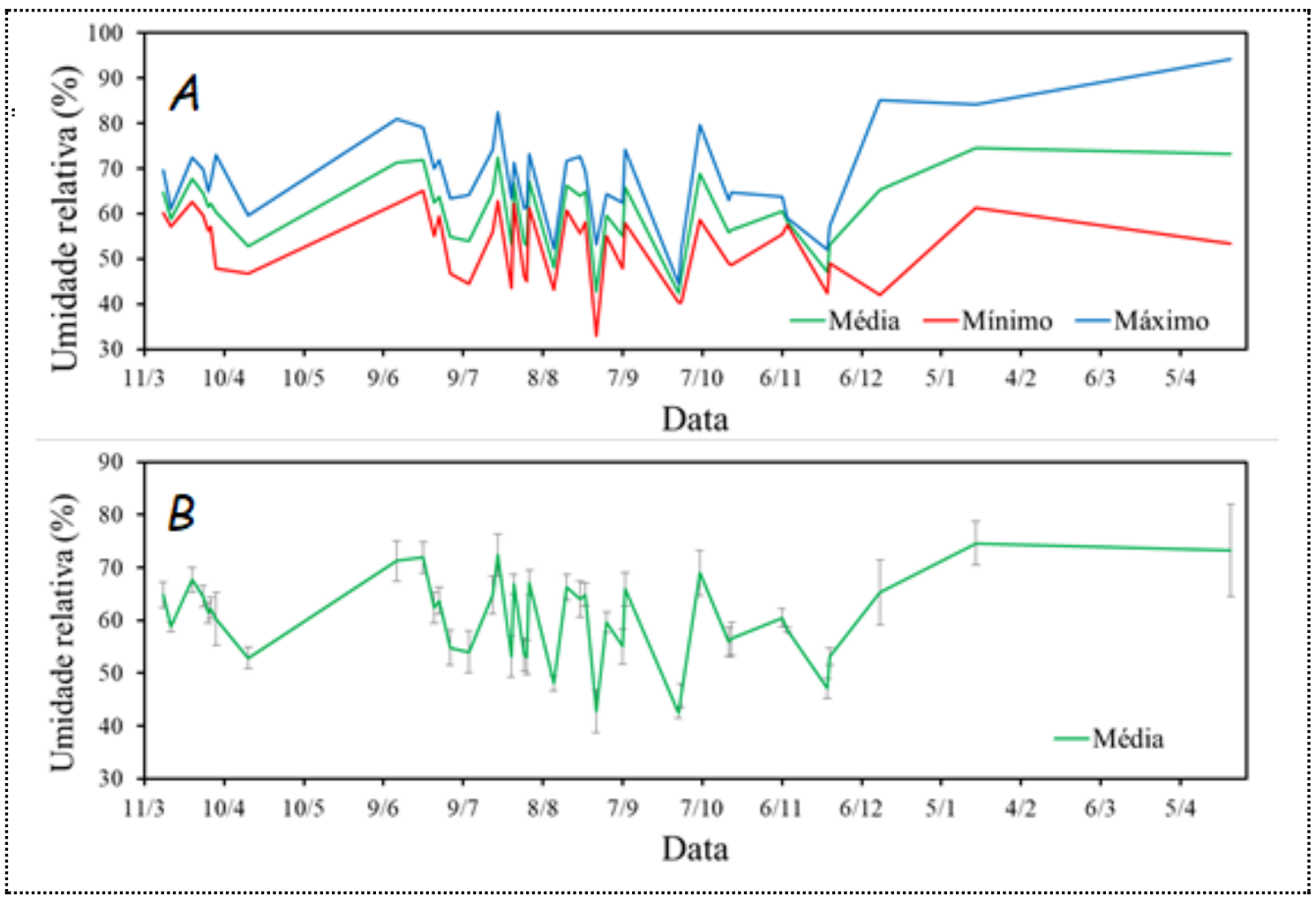

Fonte: Elaboração da autora.

O valor da umidade relativa do ar está muito associado ao sistema atmosférico predominante, ou aos sistemas que atuam sem predominarem, resultando em condições variadas de tempo, como as que se pressupõem pelo Gráfico 01 . A Tabela 02 contém episódios selecionados, seus respectivos valores de umidade, a característica da pressão e a informação de quantos dias estava sem chover no momento em que se verificou a condição mais seca.

Tabela 02 - Características dos episódios de menor umidade relativa do ar observados nos

\begin{tabular}{|c|c|c|c|c|c|}
\hline Episódio & $\begin{array}{c}\text { Menor } \\
\text { valor (\%) }\end{array}$ & $\begin{array}{l}\text { Maior } \\
\text { valor } \\
(\%)\end{array}$ & $\begin{array}{c}\text { Pressão } \\
\text { (hPa) }\end{array}$ & $\begin{array}{l}\text { Quantos dias } \\
\text { sem chover } \\
\text { no mês, } \\
\text { incluindo o } \\
\text { episódio }\end{array}$ & $\begin{array}{l}\text { Precipitação } \\
\text { acumulada } \\
(\mathbf{m m})^{\star}\end{array}$ \\
\hline $07 / 04 / 2016$ & 52,7 & 65,5 & 950,7 & 5 & 13,4 \\
\hline $19 / 04 / 2016$ & 45,9 & 59,3 & 952,8 & 17 & 13,4 \\
\hline $04 / 07 / 2016$ & 50 & 66 & 956,3 & 4 & 0 \\
\hline $11 / 07 / 2016$ & 48 & 67 & 949,2 & 3 & 4,7 \\
\hline $27 / 07 / 2016$ & 45 & 72 & 955,4 & 10 & 60,1 \\
\hline $01 / 08 / 2016$ & 47 & 72 & 955,9 & 1 & 0 \\
\hline $02 / 08 / 2016$ & 49 & 58 & 956,2 & 2 & 0 \\
\hline $12 / 08 / 2016$ & 45 & 53 & 954,7 & 3 & 15,5 \\
\hline $28 / 08 / 2016$ & 38 & 58 & 950,3 & 7 & 108,1 \\
\hline
\end{tabular}




\begin{tabular}{|c|c|c|c|c|c|}
\hline 28/09/2016 & 38 & 57 & 952,6 & 8 & 39,4 \\
\hline $29 / 09 / 2016$ & 42 & 55 & 949,1 & 9 & 39,4 \\
\hline $23 / 11 / 2016$ & 43 & 57 & 947,4 & 10 & 26,3 \\
\hline $24 / 11 / 2016$ & 50 & 63 & 949,6 & 11 & 26,3 \\
\hline
\end{tabular}

Nota-se que os episódios da Tabela 02 que tiveram atuação do ar polar, mesmo enfraquecido, 27/07, 12/08, 28 e 29/09, 23 e 24/11/2016, foram dias com valores mínimos de umidade relativa do ar, podendo ser visualizados também no Gráfico 02B. Isso ocorre porque o ar polar ao atingir a latitude em que se localiza Maringá, tende a estar muito seco, após o seu grande deslocamento latitudinal desde a área origem. A expectativa é de que o menor e o maior valor de umidade não sejam elevados, pois a influência desse anticiclone pressupõe a menor quantidade de água na atmosfera. Todos os valores máximos destacados na Tabela 02 não ultrapassam $72 \%$, e em conjunto com os dados da chuva, é possível fazer algumas associações.

O dia 19/04/2016 caracterizou-se como seco no momento do transecto, sendo que há 17 dias no mês não chovia, e a última precipitação registrada foi de 13,4 mm. O dia 27/07/2016 teve influência do ar polar enfraquecido e apesar de estar há 10 dias sem chover, a precipitação acumulada era maior do que no dia 19/04/2016. Destaca-se o mês de setembro de 2016, representado na Tabela 01 por dois episódios - 28 e 29/09 - como um mês muito seco, com 39,4 mm de precipitação. Considerando a série histórica (1980 a 2019), a média para o mês é $126,1 \mathrm{~mm}$, estando a 1 desvio padrão abaixo da média.

Os resultados apresentados na Tabela 02 podem ser visualizados no Gráfico 02A, portanto, os transectos em que se observou valores menores de umidade relativa do ar relacionam-se ao sistema atmosférico atuante e à variabilidade do vapor d'água na atmosfera devido à quantidade de dias sem chover.

Portanto, com a análise sazonal dos transectos móveis noturnos realizados em Maringá, pode-se concluir que:

- O ano de 2016 propiciou condições para a formação células de aquecimento, caracterizando-se pelo verão e outono mais chuvosos em relação à média;

- As estações de outono-inverno podem gerar o tempo anticiclônico ideal para a produção da ilha de calor, condição favorecida pela alta variabilidade dos elementos temperatura do ar e precipitação na série temporal considerada. 


\section{Considerações finais}

Com relação à variabilidade climática observada em Maringá, destaca-se que é possível esperar a ocorrência tanto de anos mais secos quanto de anos mais chuvosos, consistindo em uma dinâmica comum à série histórica de dados considerada. A alternância entre esses tipos de anos não seguiu um padrão. No que se refere à temperatura do ar, houve uma grande sequência temporal de anomalias negativas para este elemento no início da série histórica, e outra que se configurou no final da série, sendo que entre essas continuidades, anualmente houve hiatos entre anos abaixo e acima da média da temperatura do ar.

Abordar a dinâmica da ilha de calor urbana no município de Maringá demandaria mais percursos em outras extensões da malha urbana. Com a amostragem feita, os resultados referem-se aos pontos abrangidos pelos transectos móveis, não sendo possível generaliza-los para toda a área. Sendo assim, compreendeu-se que as maiores diferenças térmico-higrométrico podem ocorrer em condições específicas de tempo - anticiclônico, nebulosidade baixa, calmaria ou ventos fracos - destacando-se as estações mais frias, inverno e outono, como potenciais para que se configurem as células de aquecimento.

Este resultado se enquadra na análise da variabilidade do clima local, em que os meses representativos do outono-inverno representam os maiores desvios padrão. A cobertura vegetal arbórea desempenha importante função de amenização da temperatura e aumento da umidade relativa do ar, mas dependendo das condições sinóticas, outros fatores climáticos podem predominar como os ventos $\mathrm{e}$ as chuvas, de acordo com os sistemas atmosféricos atuantes. A linha decrescente da umidade relativa do ar observada na Figura 04 demonstra que a dinâmica da umidade relativa do ar deve ser compreendida também pelas modificações no uso e ocupação do município.

\section{REFERÊNCIAS}

AMORIM, Margarete Cristiane de Costa Trindade. llhas de calor urbanas: métodos e técnicas de análise. Revista Brasileira de Climatologia, ano 15, Edição especial, XIII Simpósio Brasileiro de Climatologia Geográfica, jun. 2019. Disponível em: < https://revistas.ufpr.br/revistaabclima/article/view/65136/38759>. Acesso em: 20 set. 2020.

BIASTOCH, Arne.; BÖNING, Claus W.; SCHWARZKOPF, Franziska U.; LUTJEHARMS, Johann Reinder Erlers. Increase in Agulhas leakage due to poleward shift of South Hemisphere westerlies. Nature, v. 462/26, nov. 2009. p. 495-499. 
BOMBARDI, Rodrigo José; CARVALHO, Leila Maria Véspoli de. The South Atlantic dipole and variations in the characteristics of the South American Monsoon in the WCRP-CMIP3 multi-models simulation. Climate Dynamics, 36, 2010. p. 2091-2102.

BOMBARDI, Rodrigo José; CARVALHO, Leila Maria Véspoli de; JONES, Charles; REBOITA, Michelle Simões. Precipitation over eastern South America and the South Atlantic Sea surface temperature during neutral ENSO periods. Climate Dynamics, 2013, p. 15531568.

CAMARGO, Eduardo Celso Gerbi; FUCKS, Suzana Druck; CÂMARA, Gilberto. Análise espacial de superfícies. In: FUCKS, Suzana Druck; CÂMARA, Gilberto, MONTEIRO, Antônio Miguel Vieira (Org.). Análise espacial de dados geográficos. EMBRAPA: 2004. p. 79-122.

CHAVES, Rosana Rodrigues. Conexões entre a TSM do Atlântico Sul e a convecção de verão sobre a América do Sul - análise observacional. Revista Brasileira de Geofísica, v. 29, n. 1, jan./mar. 2011. Disponível em: <http://dx.doi.org/10.1590/S0102-

261X2011000100001>. Acesso em: 10 fev. 2020.

CLEMENTE, Manuel Enrique Figueroa; SUÁREZ-INCLÁN, Luís Miguel. Ciudad y cambio climático. 707 medidas para luchar desde la ciudad contra el cambio climático. Puebla del Maestre: Muñoz Moya Editores Extremeños, 2009. 351 p.

CPC/NOAA. Climate Prediction Center/National Oceanic and Atmospheric Administration. Monthly Niño 3.4 index. Disponível em: < http://origin.cpc.ncep.noaa.gov/prod.ucts/analysis_monitoring/ensostuff/detrend.nino 34.ascii.txt >. Acesso em: 14 dez. 2019.

CPTEC/INPE. Centro de Previsão de Tempo e Estudos Climáticos do Instituto Nacional de Pesquisas Espaciais. 2020. Disponível em: <http://enos.cptec.inpe.br/>. Acesso em: 19 mar. 2020.

GARTLAND, Lisa. Ilhas de calor: como mitigar zonas de calor em áreas urbanas. Tradução: Sílvia Helena Gonçalves. São Paulo: Oficina de Textos, 2010. 248 p.

GOMES, Oseas Machado; SANTOS, Carlos Antonio Costa dos; SOUZA, Francisco de Assis Salviano de; PAIVA, Willian de; OLINDA, Ricardo Alves de. Análise comparativa da precipitação no estado da Paraíba utilizando modelos de regressão polinomial. In: Revista Brasileira de Meteorologia, São Paulo, v. 30, n. 1, mar. 2015. Disponível em: <http://dx.doi.org/10.1590/0102-778620120454>. Acesso em: 17 set. 2020.

GRIMM, Alice M. Clima da Região Sul do Brasil. In: CAVALCANTI, Iracema Fonseca de Albuquerque; FERREIRA, Nelson Jesus; SILVA, Maria Gertrudes Alvarez Justi da; DIAS, Maria Assunção Faus da Silva. Tempo e clima no Brasil. São Paulo: Oficina de Textos, 2009. p. 259-275.

IBGE. Divisão do Brasil em mesorregiões e microrregiões geográficas. Rio de Janeiro: IBGE, 1990. 135 p. Disponível em: <https://biblioteca.ibge.gov.br/visualizacao /monografias/GEBIS\%20-\%20RJ/DRB/Divisao\%20regional_v01.pdf>. Acesso em: 8 ago. 2017.

IBGE. 2010. Cidades e Estados. Densidade demográfica. Disponível em: < https://cidades.ibge.gov.br/brasil/pr/maringa/panorama>. Acesso em: 1 fev. 2019.

IBGE. Perfil dos municípios brasileiros: 2017. IBGE, Coordenação de População e Indicadores Sociais. Rio de Janeiro: IBGE, 2018. Disponível em: 
<https://agenciadenoticias.ibge.gov.br/media/com_mediaibge/arquivos/496bb4fbf305cca806 aaa167aa4f6dc8.pdf>. Acesso em: 19 mar. 2020.

IBGE. 2019. Cidades e Estados. População estimada. Disponível em: < https://cidades.ibge.gov.br/brasil/pr/maringa/panorama>. Acesso em: 1 fev. 2019.

INMET. Banco de dados meteorológicos para ensino e pesquisa (BDMEP). Disponível em: <http://www.inmet.gov.br/portal/index.php?r=bdmep/bdmep>. Acesso em: 7 fev. 2018.

LAKES Environmental. WRPLOT View. 2018. Freeware Wind Rose Plots for Meteorological Data. Disponível em: <https://www.weblakes.com/products/wrplot/index.html>. Acesso em: 20 set. 2020.

MINAKI; Cíntia; MONTANHER, Otávio Cristiano. Influência do El Niño-Oscilação Sul na precipitação em Maringá, no período de 1980 a 2016. Caminhos de Geografia, UberlândiaMG, v. 20, n. 69, Mar/2019, p. 266-281. Disponível em:

<http://dx.doi.org/10.14393/RCG206941220>. Acesso em: 20 fev. 2020.

OKE, Timothy; HANNEL, F. G. The form of the urban heat island in Hamilton, Canada. In: Symposium on Urban Climates and Building Climatology: Proceedings... v. 1, University of British Columbia, WMO/TD 1250.

OKE, Timothy Richard; MAXWELL, G. B. Urban heat island dynamics in Montreal and Vancouver. Atmospheric Environment, v. 9, n. 2, fev. 1975, p. 191-200. Disponível em: < https://www.sciencedirect.com/science/article/pii/0004698175900670?viac3Dih $u b>$. Acesso em: 8 fev. 2019.

QGIS DEVELOPMENT TEAM. QGIS Geographic Information System. Open Source Geospatial Foundation. 2009. Disponível em: <http://qgis.osgeo.org>. Acesso em: 30 abr. 2017.

REIS, João Bosco Coura dos; PONS, Nívea Adriana Dias; LOPES, Eymar Silva Sampaio. Monitoramento e alerta de inundação no município de Itajubá (MG) por regressão polinomial. In: Geociências, São Paulo, UNESP, v. 35, n. 1,p. 134-148, 2016. Disponível em: <http://ppegeo.igc.usp.br/index.php/GEOSP/article/view/9002>. Acesso em: 17 set. 2020.

ROMERO, Vanessa; CARRITILHA CARDOSO, Camilla; NORONHA MARCUZZO, Francisco Fernando; GONÇALVES BARROS, Rosana. Correlação da variação da temperatura na parte sul do Oceano Atlântico com a precipitação pluviométrica no estado de Goiás. In: Ciência e Natura, Santa Maria, v. 35, n. 2, 2013, p. 232-245. Disponível em: <http://www.redalyc.org/articulo.oa?id=467546171023>. Acesso em: 17 set. 2020.

SANTOS, Jeater Waldemar Maciel Correa. O clima urbano de Maringá: ensaio metodológico para cidades de porte médio e pequeno. 172 f. 1996. Dissertação (Mestrado em Geografia) - Universidade de São Paulo.

\section{NOTAS DE AUTOR}

\section{CONTRIBUIÇÃO DE AUTORIA}

Cíntia Minaki - Concepção. Coleta de dados. Análise de dados. Elaboração do manuscrito. Revisão e aprovação da versão final do trabalho.

\section{FINANCIAMENTO}

Não se aplica. 


\section{CONSENTIMENTO DE USO DE IMAGEM}

Não se aplica.

\section{APROVAÇÃO DE COMITÊ DE ÉTICA EM PESQUISA}

Não se aplica.

\section{CONFLITO DE INTERESSES}

Não se aplica.

\section{LICENÇA DE USO}

Este artigo está licenciado sob a Licença Creative Commons CC-BY. Com essa licença você pode compartilhar, adaptar, criar para qualquer fim, desde que atribua a autoria da obra.

\section{HISTÓRICO}

Recebido em: 23-03-2020

Aprovado em: 23-10-2020 